\title{
Screening for Celiac Disease in Patients with Irritable Bowel Syndrome Fulfilling Rome III Criteria
}

\author{
Khaldoon Thanoon Al-Abachi ${ }^{1}{ }^{\circledR 0}$ \\ ${ }^{1}$ Department of Medicine, University of Ninevah, Ninevah College of \\ Medicine, Mosul, Iraq
}

J Coloproctol 2022;42(1):20-24

\begin{abstract}
Address for correspondence Khaldoon Thanoon Al-Abachi, CABM, ESEGH, Department of Medicine, University of Ninevah, Ninevah College of Medicine, Mosul, Iraq (e-mail: al_abachi_kt@yahoo.com).
\end{abstract}

\begin{abstract}
Keywords

- irritable bowel syndrome

- celiac disease

- anti-tTG antibodies

- duodenal biopsy

Background Irritable bowel syndrome (IBS) is a common functional gastrointestinal disorder. Celiac disease (CD), a treatable autoimmune enteropathy, with varied presentations, may simulate clinically symptoms of IBS. The aim of the present study is to screen for CD in patients with IBS diagnosed based on the Rome III criteria.

Patients and Methods A cross-sectional study was conducted at a secondary care gastrointestinal unit in Al-Salam General Hospital in Mosul city, Iraq, from November 2015 to October 2016. All patients fulfilling the Rome III criteria for IBS were screened for CD using antitissue transglutaminase IgA antibodies (anti-tTG). Patients who tested positive were subjected to endoscopic duodenal biopsy to confirm the diagnosis of $C D$.

Results A total of 100 patients were included in the present study (58 female and 42 male), the mean age of the participants was 40.8 years old (standard deviation $[S D] \pm 11.57)$. Ten patients $(10 / 100,10 \%)$ tested positive for anti-tTG antibodies. Five of the seropositive patients $(5 / 10,50 \%)$ showed positive biopsy results according to the Marsh classification, 3 of whom having diarrhea, and 2 with constipation.

Conclusion Positive serology and biopsy results suggestive of $C D$ are common among patients with IBS. Screening patients with IBS for CD is justified.
\end{abstract}

\section{Introduction}

Irritable bowel syndrome (IBS) is a common functional bowel disorder of unestablished etiology, characterized by recurrent symptoms of abdominal pain, bloating, and altered bowel habit without detectable structural, inflammatory, or biochemical abnormalities. ${ }^{1}$ The worldwide prevalence rate is of between 10 and $15 \%{ }^{2}$ The diagnosis of IBS is based on clinical symptoms, and investigations are done to exclude organic diseases simulating IBS rather than to diagnose this disorder.

Reliable diagnostic symptom-based criteria have been established, starting with the criteria of Manning (1978), followed by Kruis et al. (1984), and later on with the emergence of the international working group that developed the Rome I (1992), Rome II (1999), Rome III (2006), and Rome IV (2016) criteria. $^{3}$ Organic diseases causing alarm received

March 21, 2021

accepted after revision

June 15, 2021

published online

November 18, 2021
DOI https://doi.org/

10.1055/s-0041-1736645.

ISSN 2237-9363.

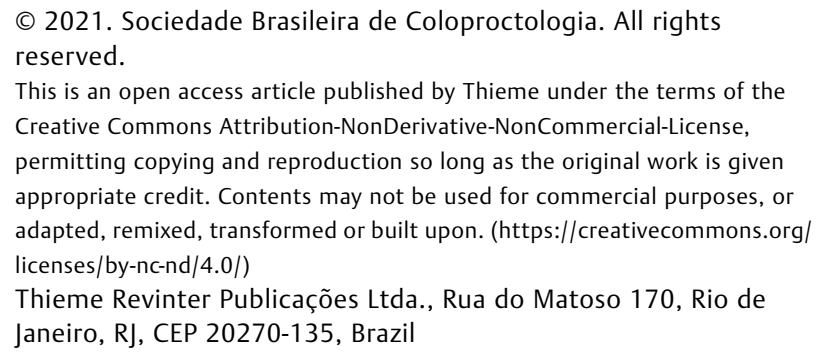

This is an open access article published by Thieme under the terms of the Creative Commons Attribution-NonDerivative-NonCommercial-License, permitting copying and reproduction so long as the original work is given appropriate credit. Contents may not be used for commercial purposes, or adapted, remixed, transformed or built upon. (https://creativecommons.org/ licenses/by-nc-nd/4.0/)

Thieme Revinter Publicações Ltda., Rua do Matoso 170, Rio de Janeiro, RJ, CEP 20270-135, Brazil 
Box 1 Rome III Criteria for Irritable Bowel Syndrome (IBS) With Subtypes

Recurrent abdominal pain or discomfort at least 3 days/month in the last 3 months with symptom onset at least 6 months
before diagnosis, associated with 2 or more of the following:
1. Improvement with defecation
2. Onset associated with a change in frequency of stools
3. Onset associated with a change in form (appearance) of stools
Subtyping IBS by Predominant Stool Pattern
1. IBS with constipation-hard or lumpy stools (IBS-C).
2. IBS with diarrhea-loose or watery stools (IBS-D).
3. Mixed IBS, diarrhea and constipation (IBS-M).

symptoms must be excluded prior to clinical diagnosis. Management of IBS depends on the amelioration of symptoms rather than on its cure.

Celiac disease (CD) is a chronic immune-mediated disorder of the small bowel initiated by the ingestion of gluten in genetically predisposed individuals. ${ }^{4}$ Gluten is a protein found in wheat, rye, and barley. It affects both children and adults, with a prevalence rate in Europe approaching $1 \%{ }^{5}$ Similar prevalence rates have been reported from the Middle East, North Africa, and India. ${ }^{6}$ Celiac disease is characterized by varied clinical presentations, including intestinal and extraintestinal manifestations. Guidelines recommend that patients suspected of having $C D$ should be screened initially with specific serological tests, and then, the diagnosis is confirmed by duodenal biopsies. Gluten free diet (GFD), which involves the lifelong elimination of wheat, rye, and barley from the diet, is the mainstay of therapy.

Symptoms of IBS may mimic the gastrointestinal symptoms of $\mathrm{CD}$; these similarities between symptoms impart difficulty in clinical differentiation. ${ }^{7}$

It has been shown that testing patients with IBS to detect undiagnosed CD using serology is cost-effective. ${ }^{8}$ Alexander et al. did a meta-analysis of 14 studies and reported a prevalence of more than 4-fold of CD in IBS cases compared with control without IBS. ${ }^{9}$ However, fewer studies did not show a higher prevalence of CD among IBS patients compared with the general population. ${ }^{10,11}$ The aim of the present study is to evaluate the frequency of positive serology and biopsy consistent with $\mathrm{CD}$ among patients presenting with symptoms of IBS fulfilling the Rome III criteria.

\section{Patients and Methods}

All patients with symptoms of IBS presenting to the secondary care gastroenterology clinic of the Al-Salam General Hospital in Mosul between November 2015 and October 2016 were attended to and offered standard medical care including clinical interview and physical examination. The patients were requested to complete a questionnaire on symptoms of IBS based on the Rome III criteria (Box 1). ${ }^{12}$

The exclusion criteria were: weight loss, anemia, jaundice, bleeding from the rectum, high erythrocyte sedimentation rate (ESR), systemic diseases, endoscopic gastrointestinal lesions, and patients reluctant to perform the serologic test.

The total number of evaluated patients was 210 , and only 100 patients were eligible to be included in the study. The age range was between 13 and 65 years old, with a mean age of 40.8 years old $(S D \pm 11.57)$. Antitissue transglutaminase IgA (Anti-tTG IgA) antibody test was used to screen the selected patients for $C D$ by measuring $\operatorname{IgA}$ antibodies to human recombinant tTG through the commercial kit Aeskulisa tTG-A 3503, a new generation of a solid phase enzyme immunoassay using human recombinant tTG crosslinked with gliadin-specific peptides. A positive test should exceed a cutoff value of $15 \mathrm{U} / \mathrm{ml}$. Other investigations included complete blood count, ESR, blood sugar, blood urea, microscopic stool examination, and, for selected patients, thyroid function test, abdominal sonography, and bone profile. All patients $>50$ years old were offered colonoscopic examination to exclude underlying organic disease. Patients with positive tTG-IgA test were subjected to upper gastrointestinal endoscopy; two biopsies were taken from the duodenal bulb and four from more distal areas. All biopsy specimens were subjected to a histopathological examination performed by expert pathologists and the results were reported based on the modified Marsh criteria. ${ }^{13}$

Data were analyzed ( - Box 2) using IBM SPSS Statistics for Windows, Version 18.0 (IBM Corp., Armonk, NY, USA). Descriptive statistics were applied to calculate the mean, median, range, percentage, p-value, and SD wherever appropriate.

The study protocol was approved by the Medical Ethics Committee of the Ninevah University and Mosul health directorate; all participants agreed to sign the written informed consent form.

\section{Results}

Out of the 100 patients diagnosed with IBS based on the Rome III criteria, 58 were female (mean age: 40.4 years old; $\mathrm{SD} \pm 12.34$ ), and 42 were male (mean age: 41.5 years old;

Box 2 Marsh-Oberhuber classification

\begin{tabular}{|l|l|}
\hline Type & Mucosal description \\
\hline 0 & Normal mucosa \\
\hline 1 & $\begin{array}{l}\text { Infiltrative lesion with more than } \\
\text { 25 lymphocytes/100 epithelial cells. }\end{array}$ \\
\hline II & Crypt hyperplasia. \\
\hline III a,b,c & Partial, subtotal, total villous atrophy. \\
\hline
\end{tabular}


Table 1 Distribution of patients according to gender and bowel habit type

\begin{tabular}{|l|l|l|l|l|}
\hline Gender & $\begin{array}{l}\text { IBS-D } \\
n ; \%\end{array}$ & $\begin{array}{l}\text { IBS-C } \\
n ; \%\end{array}$ & $\begin{array}{l}\text { IBS-M } \\
n ; \%\end{array}$ & $\begin{array}{l}\text { No.of patients } \\
\text { Total 100 }\end{array}$ \\
\hline Female & $36 / 58 ; 62.1 \%$ & $12 / 58 ; 20.7 \%$ & $10 / 58 ; 17.2 \%$ & $58 / 100$ \\
\hline Male & $20 / 42 ; 47.6 \%$ & $16 / 42 ; 38.1 \%$ & $6 / 42 ; 14.3 \%$ & $42 / 100$ \\
\hline
\end{tabular}

Abbreviation: IBS, irritable bowel syndrome.

$\mathrm{SD} \pm 10.54)$. Their bowel habit characteristics are shown in (-Table 1).

The duration of symptoms ranged from 1 to 32 years (mean: 10.3 years). Ten patients ( 7 female and 3 male) out of the of the total 100 (10\%) tested positive for tTG-IgA antibody $(p<0.00001$ compared with a CD seroprevalence rate of $2 \%$ in some normal populations). ${ }^{6}$ Five patients ( 3 female, 2 male) of the 10 seropositive $(5 / 100,5 \%)$ showed abnormal histopathological changes according to the modified Marsh criteria (2 Marsh I, 1 Marsh II, and 2 Marsh IIIc), and 3 patients displayed Marsh 0 (negative biopsy result). Two seropositive patients refused to undergo duodenal biopsy. Five of the 10 seropositive patients $(5 / 10 ; 50 \%)$ had predominantly diarrhea, $3(3 / 10 ; 30 \%)$ had predominantly constipation, and $2(2 / 10 ; 20 \%)$ had a mixed pattern. The characteristics of the seropositive patients are shown in (-Table 2).

\section{Discussion}

Despite being a common gastrointestinal disorder and the development of symptom-based parameters to diagnose IBS, there is no clinical criterion or result of investigation that is pathognomonic of IBS. ${ }^{14}$ Further confusing the issue, symptoms of IBS frequently overlap and may coexist with symptoms of other gastrointestinal and nongastrointestinal disorders. $^{15}$

In the present study, patients were selected according to the Rome III criteria, which are more suitable for the definition of the symptoms of our patients compared with other criteria, considering the duration of symptoms and subtyping of bowel habits.

Patients were screened serologically by IgA-tTG antibody test alone to detect $\mathrm{CD}$. It is an enzyme-linked immunoassay (ELISA) test, operator independent, and is recommended as a screening test for $\mathrm{CD}$, with a sensitivity of $94 \%$ and a specificity of $97 \%{ }^{16}$

Reports from different regions in the world showed mostly an increased prevalence of CD in patients with IBS compared with the general population, and fewer reports showing no such increase (- Table 3). ${ }^{10,17-23}$

A large meta-analysis by Irvine et al. involving 36 studies found a higher prevalence of positive serology and biopsy for CD in patients with IBS compared with healthy controls. ${ }^{24}$ Another study, by Almazar et al., conducted in a USA tertiary care center and recruiting 533 patients and 531 controls, found no difference in the prevalence of $C D$ between patients with IBS and controls. ${ }^{25}$ Recently, Mohammad et al. from Iraq detected 5 seropositive patients for $\mathrm{CD}(7.1 \%)$ in a sample of 70 patients with IBS fulfilling the Rome III criteria. ${ }^{26}$ This variation in results might be ascribed to different geographical locations, racial differences, study characteristics, sample size, and selection bias.

In the present study, three seropositive patients had negative biopsy results (Marsh 0) and two showed Marsh grade $\mathrm{I}$, which is nonspecific for $\mathrm{CD}$. Both grades are regarded as potential $C D$, which means that these patients are at increased risk of developing overt $\mathrm{CD}$ in the future. ${ }^{27}$ Also, Marsh grade II lacks diagnostic support for $C D$, while villous atrophy, which was identified in two of the seropositive

Table 2 Characteristics of seropositive patients

\begin{tabular}{|l|l|l|l|l|l|l|}
\hline Patient no. & Age (years old) & Gender & IBS subtype & $\begin{array}{l}\text { tTG-IgA U/mI } \\
\text { cutoff: 15 }\end{array}$ & Marsh type & $\begin{array}{l}\text { Duration of } \\
\text { symptoms (years) }\end{array}$ \\
\hline 1 & 23 & F & IBS-D & 18.6 & 0 & 8 \\
\hline 2 & 48 & F & IBS-M & 35 & 0 & 8 \\
\hline 3 & 48 & F & IBS-C & 16 & 0 & 6 \\
\hline 4 & 34 & F & IBS-D & 17.9 & I & 5 \\
\hline 5 & 45 & F & IBS-D & 17.1 & I & 10 \\
\hline 6 & 51 & M & IBS-C & 41.16 & II & 13 \\
\hline 7 & 28 & M & IBS-C & 98.88 & III C & 15 \\
\hline 8 & 46 & F & IBS-D & 166.8 & III C & 20 \\
\hline 9 & 30 & M & IBS-M & 18.2 & Refused biopsy & 5 \\
\hline 10 & 34 & F & IBS-D & 100 & Refused biopsy & 1 \\
\hline
\end{tabular}

Abbreviations: F, female; IBS, irritable bowel syndrome; M, male. 
Table 3 Studies of celiac disease in patients with irritable bowel syndrome

\begin{tabular}{|l|l|l|l|}
\hline Authors (Ref.) & Country & Number of patients & Prevalence of CD \\
\hline Sanders et al. ${ }^{17}$ & UK & 300 & $4.7 \%$ \\
\hline Sanders et al. & UK & 123 & $3.3 \%$ \\
\hline Fasano et al. $^{19}$ & USA & 5073 & $\begin{array}{l}3.85 \% \text { with diarrhea } \\
\mathbf{2 . 6 \%} \text { with constipation }\end{array}$ \\
\hline Shahbazkhani et al. $^{20}$ & & & $11.4 \%$ \\
\hline Jadallah et al. $^{21}$ & Iran & 105 & $3.2 \%$ \\
\hline Korkut et al. $^{22}$ & Jordan & 742 & $2 \%$ \\
\hline El-Sahly et al. & Turkey & 100 & $0.4 \%$ \\
\hline Hin et al. & & 968 & $0 \%$ \\
\hline
\end{tabular}

Abbreviation: $\mathrm{CD}$, celiac disease.

patients, is more typical of $\mathrm{CD} .^{28}$ These two patients with total villous atrophy displayed a very high titer of tTG-IgA antibody level. Studies in children and adults with CD have concluded that serum tTG antibody level correlates positively with the severity of small intestinal histopathology. ${ }^{29}$ One female patient, 34 years old, with high tTg-antibody titer ( $100 \mathrm{U} / \mathrm{ml}$ ) did not undergo endoscopy and biopsy, and it is highly expected that this patient has CD.

The classic presentation of adult CD is diarrhea, which was identified in 5 of the seropositive patients (50\%). Constipation is not an uncommon symptom in adult $\mathrm{CD}^{30}$ and it was present in 3 seropositive patients (30\%).

Four of the seropositive patients $(4 / 10 ; 40 \%$ ) ( 1 with Marsh grade II, 2 with Marsh grade IIIc, and 1 female patient with an antibody titer of $100 \mathrm{U} / \mathrm{ml}$ who refused biopsy) responded to GFD within a period of 4 weeks, with improvement in the general well-being and intestinal symptoms. Improvement of clinical symptoms on GFD is not enough to confirm the diagnosis of $C D$, since a subset of patients with IBS may also improve on GFD. ${ }^{31}$ To be more stringent in the diagnosis of $C D$, an improvement on diet should be supported by serial measurements of serum antibody level and possibly repeated duodenal biopsy after a reasonable follow-up period (between 3 and 6 months). It was not possible to confirm the actual prevalence of $C D$ in all seropositive patients in our sample, as many of them are noncompliant with extended future followup and doing necessary tests. Anyway, we can roughly estimate the prevalence of $C D$ in the IBS patients included in the present study to be not less than $3 \%$ ( $p=0.02$ compared with a $1 \%$ prevalence rate in normal populations), which is comparable with the results of many other studies.

The patients included in the present study were referred from primary care health centers and represent more severe and chronic conditions of IBS, which may have an impact on the ultimate prevalence of $C D$ in patients who manifested symptoms of IBS.

\section{Conclusion}

In the present study, the frequency of positive anti-tTG antibody test in patients with IBS based on the Rome III criteria was of $10 \%$, and the likelihood of CD in these patients was high (at least 3\%).

Antibody testing for CD in patients who fulfill the IBS diagnostic criteria is recommended in Mosul, Iraq.

Further well-controlled studies including larger samples of patients are needed and follow-up of seropositive and biopsy-positive patients to ascertain the diagnosis of $C D$ is required, which includes GFD, repeated serology tests, and duodenal biopsy.

\section{Ethical Approval}

Ethical approval was granted by the Medical Ethics Committee of the Ninevah University.

\section{Informed Consent}

All participant agreed to sign an informed written consent form.

Note

Hospital-based study supported by Iraqi ministry of health. The patients were not charged, and no charge was received by the author.

Conflict of Interests

The author has no conflict of interests to declare.

\section{Acknowledgement}

The author would like to express his thanks and gratitude to the staff of the Laboratory Department, Pathology Department, and Endoscopy Unit of the Al-Salam General Hospital in Mosul for their support and cooperation during the execution of the present study.

\section{References}

1 Brandt LJ, Chey WD, Foxx-Orenstein AE, et al; American College of Gastroenterology Task Force on Irritable Bowel Syndrome. An evidence-based position statement on the management of irritable bowel syndrome. Am J Gastroenterol 2009;104(Suppl 1):S1-S35

2 Drossman DA, Camilleri M, Mayer EA, Whitehead WE. AGA technical review on irritable bowel syndrome. Gastroenterology 2002;123(06):2108-2131 
3 Lacy BE, Patel NK. Rome Criteria and a Diagnostic Approach to Irritable. Bowel Syndrome. J Clin Med 2017;06(11):1-8

4 Di Sabatino A, Corazza GR. Coeliac disease. Lancet 2009;373 (9673):1480-1493

5 West J, Logan RF, Hill PG, et al. Seroprevalence, correlates, and characteristics of undetected coeliac disease in England. Gut 2003;52(07):960-965

6 Malekzadeh R, Sachdev A, Fahid Ali A. Coeliac disease in developing countries: Middle East, India and North Africa. Best Pract Res Clin Gastroenterol 2005;19(03):351-358

7 Wahnschaffe U, Ullrich R, Riecken EO, Schulzke JD. Celiac diseaselike abnormalities in a subgroup of patients with irritable bowel syndrome. Gastroenterology 2001;121(06):1329-1338

8 Spiegel BM, DeRosa VP, Gralnek IM, Wang V, Dulai GS. Testing for celiac sprue in irritable bowel syndrome with predominant diarrhea: a cost-effectiveness analysis. Gastroenterology 2004; 126(07):1721-1732

9 Ford AC, Chey WD, Talley NG, et al. Yeild of diagnostic tests for celiac disease in individuals with symptoms suggestive of irritable bowel syndrome: systematic review and meta-analysis. Arch Intern Med 2009;169(07):651-658

10 Hin H, Bird G, Fisher P, Mahy N, Jewell D. Coeliac disease in primary care: case finding study. BMJ 1999;318(7177): 164-167

11 Cash BD, Rubenstein JH, Young PE, et al. The prevalence of celiac disease among patients with nonconstipated irritable bowel syndrome is similar to controls. Gastroenterology 2011;141(04):1187-1193

12 Longstreth GF, Thompson WG, Chey WD, Houghton LA, Mearin F, Spiller RC. Functional bowel disorders. Gastroenterology 2006; 130(05):1480-1491

13 Oberhuber G, Granditsch G, Vogelsang H. The histopathology of coeliac disease: time for a standardized report scheme for pathologists. Eur J Gastroenterol Hepatol 1999;11(10): 1185-1194

14 Burbige EJ. Irritable bowel syndrome: diagnostic approaches in clinical practice. Clin Exp Gastroenterol 2010;3:127-137

15 Frissora CL, Koch KL. Symptom overlap and comorbidity of irritable bowel syndrome with other conditions. Curr Gastroenterol Rep 2005;7(04):264-271

16 Zintzaras E, Germenis AE. Performance of antibodies against tissue transglutaminase for the diagnosis of celiac disease: meta-analysis. Clin Vaccine Immunol 2006;13(02):187-192

17 Sanders DS, Carter MJ, Hurlstone DP, et al. Association of adult coeliac disease with irritable bowel syndrome: a case-control study in patients fulfilling ROME II criteria referred to secondary care. Lancet 2001;358(9292):1504-1508
18 Sanders DS, Patel D, Stephenson TJ, et al. A primary care crosssectional study of undiagnosed adult coeliac disease. Eur J Gastroenterol Hepatol 2003;15(04):407-413

19 Fasano A, Berti I, Gerarduzzi T, et al. Prevalence of celiac disease in at-risk and not-at-risk groups in the United States: a large multicenter study. Arch Intern Med 2003;163(03):286-292

20 Shahbazkhani B, Forootan M, Merat S, et al. Coeliac disease presenting with symptoms of irritable bowel syndrome. Aliment Pharmacol Ther 2003;18(02):231-235

21 Jadallah KA, Khader YS. Celiac disease in patients with presumed irritable bowel syndrome: a case-finding study. World J Gastroenterol 2009;15(42):5321-5325

22 Korkut E, Bektas M, Oztas E, Kurt M, Cetinkaya H, Ozden A. The prevalence of celiac disease in patients fulfilling Rome III criteria for irritable bowel syndrome. Eur J Intern Med 2010;21(05):389-392

23 El-Salhy M, Lomholt-Beck B, Gundersen D. The prevalence of celiac disease in patients with irritable bowel syndrome. Mol Med Rep 2011;4(03):403-405

24 Irvine AJ, Chey WD, Ford AC. Screening for Celiac Disease in Irritable Bowel Syndrome: An Updated Systematic Review and Meta-analysis. Am J Gastroenterol 2017;112(01):65-76

25 Almazar AE, Talley NJ, Larson JJ, Atkinson EJ, Murray JA, Saito YA. Celiac disease is uncommon in irritable bowel syndrome in the USA. Eur J Gastroenterol Hepatol 2018;30(02):149-154

26 Mohammad BY, Al-Dohouky L, Mohammed AA. Prevalence of antitissue transglutaminase antibodies in patients with irritable bowel syndrome in Duhok city. J Coloproctol (Rio J) 2019;39(04):346-350

27 Ludvigsson JF, Leffler DA, Bai JC, et al. The Oslo definitions for coeliac disease and related terms. Gut 2013;62(01):43-52

28 Hill ID, Dirks MH, Liptak GS, et al; North American Society for Pediatric Gastroenterology, Hepatology and Nutrition. Guideline for the diagnosis and treatment of celiac disease in children: recommendations of the North American Society for Pediatric Gastroenterology, Hepatology and Nutrition. J Pediatr Gastroenterol Nutr 2005;40(01):1-19

29 Donaldson MR, Firth SD, Wimpee H, et al. Correlation of duodenal histology with tissue transglutaminase and endomysial antibody levels in pediatric celiac disease. Clin Gastroenterol Hepatol 2007; 5(05):567-573

30 Spijkerman M, Tan IL, Kolkman JJ, et al. A large variety of clinical features and concomitant disorders in celiac disease - A cohort study in the Netherlands. Dig Liver Dis 2016;48(05):499-505

31 Vazquez-Roque MI, Camilleri M, Smyrk T, et al. A controlled trial of gluten-free diet in patients with irritable bowel syndromediarrhea: effects on bowel frequency and intestinal function. Gastroenterology 2013;144(05):903-911.e3 